\title{
Groupers (Pisces: Serranidae) in fished and protected areas of the Florida Keys, Bahamas and northern Caribbean
}

\author{
Mark Chiappone*, Robert Sluka, Kathleen Sullivan Sealey \\ The Nature Conservancy, Marine Conservation Science Center, University of Miami, Department of Biology,
} PO Box 249118, Coral Gables, Florida 33124, USA

\begin{abstract}
Groupers (Pisces: Serranidae) of littoral environments of warm-temperate and tropical regions have experienced intense fishery exploitation. Indicators of intense fishing include declines or change in abundance, size, spawning aggregations, and species composition. Surveys of grouper were carried out from 1995 to 1997 in the Florida Keys, central Bahamas, southeastern Cuba, and the southeastern Dominican Republic to illuminate patterns in species composition, abundance, and size, along a gradient of relative fishing pressure. We assumed that the diversity, composition, density, and size would serve as indicators of fishing pressure in these areas. The study locations included 2 national parks and a national marine sanctuary, and were categorized as: (1) intensively fished with little or no management for groupers (southeastern Cuba, southeastern Dominican Republic), (2) intensively fished with numerous gear and effort regulations (Florida Keys), (3) lightly fished with some gear and effort regulations (northern and southern Exuma Cays, Bahamas), and (4) a no-take marine fishery reserve closed to fishing (Exuma Cays Land and Sea Park, Bahamas). On each site 10 to 20 strip transects $(20 \mathrm{~m} \times 5 \mathrm{~m})$ were surveyed in water of 1 to $20 \mathrm{~m}$ depth over rocky hard-bottom habitats for density and size of grouper. Nine grouper species (2 Cephalopholis spp., 4 Epinephelus spp., and $3 \mathrm{Myc}$ teroperca spp.) were documented among all areas. Results show that areas where grouper fishing was relatively light had greater numbers of species, density, and biomass, particularly for larger species such as Nassau grouper E. striatus. Classification of groupers by 3 life history categories or growth strategies (small, intermediate, and large) indicated significant differences in density and biomass among study areas. The density and biomass of larger grouper species were significantly greater in the no-take marine reserve and lightly fished areas than in the more intensively fished areas. In 3 of the areas characterized as intensively fished, one of which has several grouper fishery regulations, grouper density and biomass were dominated by small, non-targeted species such as the graysby $C$. cruentatus and the coney $C$. fulva. This pattern may indicate a second-order effect of fishing, indicative of potential changes in competition or predation. No-take marine fishery reserves represent a viable means to protect grouper resources, simplifying enforcement relative to complex catch and effort regulation, but also potentially alleviating the need to gather fisheries-dependent data.
\end{abstract}

KEY WORDS: Caribbean · Groupers · Marine fishery reserve · Overfishing

\section{INTRODUCTION}

Groupers (Serranidae, Epinephilinae) are important top-level predators in coral reef ecosystems worldwide

\footnotetext{
*Present address: University of North Carolina at Wilmington, The National Undersea Research Center, 515 Caribbean Drive, Key Largo, Florida 33037, USA.

E-mail: mark@benthos.cox.miami.edu
}

(Parrish 1987). They are highly sedentary, living near the bottom in holes, caves, and crevices. Groupers occupy a variety of habitats over a wide depth range $(1$ to $300 \mathrm{~m})$ and feed primarily upon fishes and crustaceans (Nagelkerken 1981, Parrish 1987, Sluka \& Sullivan 1996a). Many species can attain large sizes ( $>100 \mathrm{~cm}$ total length [TL]). Moderate to large species are characterized by slow growth, delayed reproduction, long life span, reduced spawning period, and 


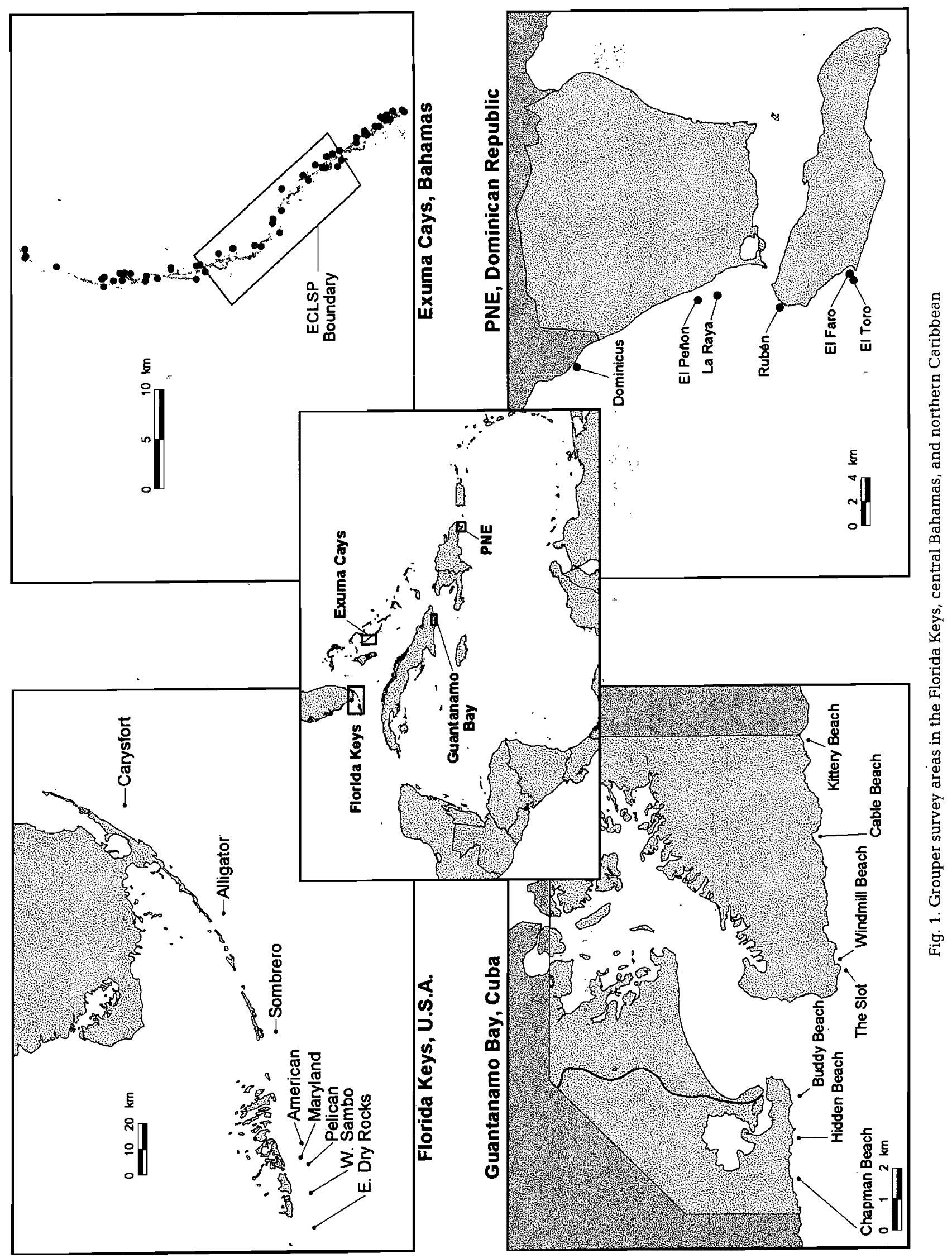


possible protogynous sex reversal (Sadovy 1994). In addition, several species exhibit aggregate spawning behavior (Smith 1972, Shapiro 1987).

Groupers are prized food fishes in both recreational and commercial fisheries (Bohnsack et al. 1994, Carter et al. 1994), but have experienced marked declines in abundance, size, landings, and catch per unit effort due to severe exploitation (Gobert 1994, Huntsman et al. 1994, Sadovy 1994). In many instances, overfishing of spawning aggregations has been the cause of decline in diverse areas such as the eastern Caribbean (Beets \& Friedlander 1992), Belize (Carter et al. 1994), Mexico (Aguilar-Perera \& Aguilar-Davila 1996) and Bermuda (Luckhurst 1996). Nassau grouper Epinephelus striatus and other large species are particularly vulnerable to fishing, even at moderate levels, because of their life history characteristics (Olsen \& LaPlace 1978, Huntsman \& Schaaf 1994). Intense fishing pressure tends to decrease the abundance and average size of fish (Ferry \& Kohler 1987, PDT 1990, Beets \& Friedlander 1992), but can also result in the decline of spawning aggregations (Carter et al. 1994, AguilarPerera \& Aguilar-Davila 1996), changes in species composition (Goeden 1982), and an increase in the abundance of non-targeted species (Bohnsack 1982, Sluka \& Sullivan 1996b). Conventional catch and effort regulations for grouper fisheries evidently have not prevented stocks from being overfished (Bohnsack et al. 1994, Huntsman et al. 1994), likely due to a combination of inadequate enforcement, lack of biological knowledge and socioeconomic factors (Sadovy 1994). For example, the Nassau grouper is now federally protected in the United States (Bohnsack et al. 1994) and has declined to such a degree in the US Virgin Islands and Puerto Rico, due possibly to overfishing of spawning aggregations, that it is now considered economically extinct (Sadovy 1994).

One management option that has been proposed to combat overfishing is to establish marine fishery reserves, also referred to as no-take marine reserves or harvest refugia. A marine reserve constitutes a defined space to which some form of management and limited entry is applied or constitutes areas permanently closed to consumptive usage (PDT 1990, Dugan \& Davis 1993). The benefits of no-take marine reserves for intensively fished species such as grouper are numerous, and such reserves afford types of protection not provided by other forms of management: protection of spawning stock biomass, maintenance of genetic variability, enhancement of fisheries yield to adjacent areas through emigration, and enhancement of larval production to replenish other areas (Russ 1985, Russ et al. 1992, Polunin \& Roberts 1993, Sluka et al. 1997). Marine reserves may also increase or preserve high species diversity and increase economic gain (Russ \& Alcala 1989).
The focus of this study was to assess grouper resources through underwater visual transects in northern areas of the wider Caribbean. The main goal of this study was to evaluate fishing pressure influence (reflecting fishery management regimes) on grouper assemblages. This was achieved by: (1) surveying areas differing in fishing intensity, development of catch and effort regulations, and (2) comparing grouper species composition, density, and biomass along a gradient of relative fishing pressure. We reasoned that the density and biomass of predatory fishes such as groupers would provide an excellent indicator of the effects of marine reserve protection and fishing (Russ \& Alcala 1996). Results from the present study could provide evidence of second-order effects of fishing and have implications for the recovery potential of heavily fished coastal areas. Although juvenile and adult groupers may show specific habitat preferences (Nagelkerken 1981, Shpigel \& Fishelson 1989), these analyses are presented elsewhere (Sluka et al. 1996a,b, Sluka \& Sullivan 1996a,b).

\section{METHODS}

Study sites. Four regions of the northern wider Caribbean were surveyed for grouper species composition, density, and size from 1995 to 1997 . These are the Florida Keys, central Bahamas, southeastern Cuba, and the southeastern Dominican Republic (Fig. 1). Six study areas, with a total of 70 sites representing coral reef and low-relief hard-bottom habitats were sampled over a 1 to $20 \mathrm{~m}$ depth range (Table 1 ). The descriptions of these bottom types are presented elsewhere (Sluka et al. 1996b, Vega et al. 1996, Chiappone \& Sullivan 1997, Chiappone et al. 1997). For data analysis and statistical computations, the study areas were classified according to relative fishing pressure, possibly indicative of grouper fishery management regimes (Table 2).

Southeastern Cuba and the southeastern Dominican Republic were classified as intensively fished with little or no catch or effort regulations for grouper. In southeastern Cuba, reefs were surveyed within the boundaries of the US Naval Base at Guantanamo Bay, where destructive fishing practices are prohibited. There are no fishing restrictions such as catch quotas, minimum size, or area closures for groupers, however, and grouper fishing is primarily for recreational purposes; the main fishing methods used are spearguns and hook-and-line.

In the southeastern Dominican Republic, 6 of the 7 sites surveyed were in the Parque Nacional del Este, a large, coastal national park. Established in 1975, Parque Nacional del Este is the second largest pro- 
Table 1. Sampling effort and habitat characteristics of grouper survey areas in the Florida Keys, central Bahamas, southeastern Cuba, and southeastern Dominican Republic. GTMO: Guantanamo Bay Naval Base, southeastern Cuba; N Exumas: northern Exuma Cays, central Bahamas; S Exumas: southern Exuma Cays, central Bahamas; ECLSP: Exuma Cays Land and.Sea Park, central Bahamas

\begin{tabular}{|lllr|}
\hline Location (date) & No. of sites (transects) & Habitat & Depth (m) \\
\hline GTMO (Jul-Aug 1996) & $8(112)$ & High-relief spur and groove & $5-14$ \\
SE Dominican Republic (Apr 1997) & $1(20)$ & Reef ridge & $10-12$ \\
& $3(60)$ & Low-relief spur and groove & $15-20$ \\
& $1(20)$ & Rocky outcrops & $15-17$ \\
Florida Keys (Jun-Aug 1995) & $2(40)$ & Low-relief hard-bottom & $15-18$ \\
& $5(100)$ & High-relief spur and groove & $3-9$ \\
N Exumas (Oct-Nov 1995) & $3(56)$ & Relict reef flat & $4-10$ \\
& $7(70)$ & Channel reef & $3-10$ \\
& $7(70)$ & Fringing reef & $1-19$ \\
ECLSP (Oct-Nov 1995) & $7(70)$ & Low-relief hard-bottom & $4-10$ \\
- & $6(60)$ & Channel reef & $2-11$ \\
S Exumas (Oct-Nov 1995) & $7(70)$ & Fringing reef & $2-15$ \\
& $6(60)$ & Low-relief hard-bottom & $3-12$ \\
& $6(60)$ & Channel reef & $3-11$ \\
& $3(30)$ & Fringing reef & $1-15$ \\
& $6(60)$ & Low-relief hard-bottom & $4-9$ \\
\hline
\end{tabular}

Table 2. Grouper fishery characteristics and existing management regulations in the Florida Keys, central Bahamas, and northern Caribbean. MFR: marine fishery reserve; GTMO: Guantanamo Bay Naval Base, southeastern Cuba; ECLSP: Exuma Cays Land and Sea Park, central Bahamas

\begin{tabular}{|c|c|c|c|c|}
\hline \multirow{2}{*}{ Classification/area } & \multirow{2}{*}{ Gear types } & \multirow[b]{2}{*}{ Quotas } & Regulations & \multirow[b]{2}{*}{ MFR } \\
\hline & & & Size limit & \\
\hline \multicolumn{5}{|l|}{ Heavily fished/little management } \\
\hline GTMO & Spears, hook-and-line & & & \\
\hline SE Dominican Republic & Spears, hook-and-line, traps & & & \\
\hline Heavily fished/high management & · & & & \\
\hline Florida Keys & Spears, hook-and-line & $x$ & $x$ & \\
\hline \multicolumn{5}{|l|}{ Lightly fished/moderate management } \\
\hline $\mathrm{N}$ Exumas & Spears, hook-and-line, traps & & $x$ & \\
\hline S Exumas & Spears, hook-and-line, traps & & $x$ & \\
\hline \multicolumn{5}{|l|}{ No fishing/high management } \\
\hline ECLSP & No fishing allowed & & & $x$ \\
\hline
\end{tabular}

tected area in the Dominican Republic, comprising over $434 \mathrm{~km}^{2}$ of terrestrial habitats and an additional $120 \mathrm{~km}^{2}$ of shallow-water $(<30 \mathrm{~m})$ marine habitats. Fishermen originate from 4 small villages and towns within and adjacent to the park. Most fishing is artisanal in nature and is conducted from small $(<7 \mathrm{~m})$ sailing sloops or yolas. Fishermen use a variety of gear types, but the majority ( $>80 \%$ ) of fishing is done using hook-and-line and spears (G. Bustamante, The Nature Conservancy, pers. comm.). Fishes most targeted include species of Serranidae, Lutjanidae, Balistidae, and Scaridae. Historical data are lacking on exploitation patterns and the status of grouper resources in the park (Towle et al. 1973, Vega et al. 1996). Towle et al.
(1973) reported 25 yr ago that conch, lobster, and reef fish were severely depleted in many areas of Parque Nacional del Este, particularly from spearfishing and commercial fleet operations prevalent from the 1950 s to the early 1970 s.

The Florida Keys are situated at the northern edge of the distribution of many tropical groupers. However, the catch composition here is generally similar to some areas of the Caribbean (Bohnsack et al. 1994). Grouper survey sites are all located in the Florida Keys National Marine Sanctuary, a $9515 \mathrm{~km}^{2}$ protected area established in 1990. A commercial fishery for groupers has existed in the Florida Keys since the mid-1800s. In the federally managed US South Atlantic, 14 species are 
considered important in the commercial and recreational fisheries (Huntsman et al. 1994). The entire Florida Keys area is heavily fished year round with seasonal peaks during the winter tourist season and summer months. The fisheries are extremely complex because of the large number of species targeted, different kinds of gear used, number of access points, and many different objectives among fishing interests (Bohnsack et al. 1994).

Fisheries-dependent data from the Florida Keys suggest that grouper landings and catch composition have changed dramatically because of increased commercial and recreational fishing (Bohnsack 1990, Bohnsack et al. 1994). Commercial and headboat landings for total grouper $(\mathrm{kg})$ declined from 1977 to 1992. Recent multi-species stock analyses have shown that 13 of the 16 grouper species in the Florida Keys are below the $30 \%$ spawning potential ratio, which is defined as a state of overfishing by the Federal Fishery Management Council (Ault et al. 1998). Fishermen use spear guns and hook-and-line in the sanctuary. Black grouper Mycteroperca bonaci and red grouper Epinephelus morio are the most important by weight in available landings data (Bohnsack et al. 1994). $M$. bonaci is not considered overfished according to the South Atlantic Fisheries Management Council (but see Ault et al. 1998); however, several other species are considered overfished based on spawning stock per recruit ratio (Huntsman et al. 1994; Ault et al. 1998). Carysfort Reef (Fig. 1) has been protected from spearfishing and trap fishing since 1975 and 1980, respectively. Jewfish E. itajara and Nassau grouper E. striatus have been protected from all forms of fishing since 1990 and 1991, respectively. Fish traps have been banned in federal waters since 1980 . There are recreational and commercial catch quotas and minimum size regulations for several species currently in effect.

Three separate areas were surveyed in the central Bahamas: northern Exuma Cays, Exuma Cays Land and Sea Park, and southern Exuma Cays. The northern and southern Exuma Cays were classified as lightly fished with moderate management. Artisanal and commercial fishermen primarily target Nassau grouper Epinephelus striatus; this species is the third most important commercial fishery (behind spiny lobster and queen conch) and the most important finfish species in the Bahamas. Most of the landings are generated from the fishing of spawning aggregations from December to February at several locations such as Andros, Cat Island, and Long Island (Sadovy in press). Only $2 \%$ of the roughly $17619 \mathrm{t}$ annual catch (worth over US $\$ 1.7$ million) originates from the Exuma Cays; however, this does not include groupers caught for local consumption (V. Deleveaux, Bahamas Department of Fisheries, pers. comm.). Other large grouper species (e.g., Mycteroperca spp.) are generally not targeted, but are likely fished incidentally by hook-andline and trap fishing. Fishing methods in the northern Exumas include spearguns, traps and hook-and-line, while spearguns and hook-and-line are mainly used in the southern Exumas.

Between the northern and southern Exuma Cays regions lies the Exuma Cays Land and Sea Park (ECLSP), a no-take marine reserve. The ECLSP encompasses a $35 \mathrm{~km}$ long section of the Exuma Cays, covering an area of $442 \mathrm{~km}^{2}$. The park was established by the Government of the Bahamas in July 1958, under the National Trust Act, to preserve the natural heritage of the Bahamas (Fig. 1). The following year, the Bahamas National Trust (BNT), a non-governmental organization, was created by an Act of Parliament and mandated with the responsibilities and powers to manage the ECLSP and any future national parks. Initially, limited fishing was allowed in the park, but by the 1980s fishing pressure in the park had apparently increased dramatically, and the BNT changed the park by-laws in 1986 to make the entire area closed to all forms of fishing. A park warden has been on-site since 1989. A volunteer support fleet and the Bahamian Defense Force presently assist one warden. The park is subjected to some level of poaching, as reflected for example by the decreased abundance and biomass of Nassau grouper away from the park ranger station (Sluka et al. 1996b, 1997).

Grouper surveys. 10 to 20 transects measuring $20 \mathrm{~m} \times 5 \mathrm{~m}$ in area were haphazardly placed in hardbottom habitats in each of the 6 study areas at depths of 1 to $20 \mathrm{~m}$. Groupers were visually surveyed for number and TL. Transect width was visually estimated and observers were trained to accurately estimate transect width by swimming the length of a transect and placing construction flags at an estimated distance of $2.5 \mathrm{~m}$ out on each side of the line. The average estimated distance was compared to the desired estimate and biases made known to the observers. Observers were also trained to estimate fish length to the nearest $\mathrm{cm}$ by swimming past a series of fish models and visually estimating their sizes (Bell et al. 1985). Results were compared to known lengths for each model and the individual biases made known to the observers. In the Exuma Cays, 10 transects per site were surveyed based on desired precision levels $(>20 \%)$ and pilot studies (Sluka et al. 1997). In all other areas, generally 16 to 20 transects per site were surveyed due to the low density of groupers, particularly larger species. Seventy sites and 958 transects were surveyed in total (Table 1).

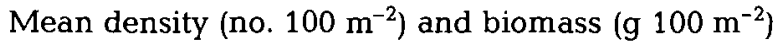
of species were computed for each of the 6 study areas based upon mean values calculated from site-level 
(transects) data. Length values were converted to biomass using known length-weight relationships (Thompson \& Munro 1978, Manooch \& Mason 1987, Claro \& Garcia-Arteaga 1994, Potts \& Manooch 1995, Sadovy \& Colin 1995). Relative percent density and biomass metrics were computed based on each species contribution to the total in each of the 6 study areas. Parametric or non-parametric (Kruskal-Wallis test) analysis of variance was used to detect significant differences in density and biomass among the 6 study areas (Zar 1996). Variance homogeneity was examined using Bartlett's test and monotonic transformations applied prior to ANOVA. Tukey's honestly significant difference test or the non-parametric analog was used as a multiple comparison test (Zar 1996). Comparisons in density and biomass were also made among study areas according to grouper life history categories. Grouper species were divided into 3 general categories based on growth history: small, intermediate, and large (Shapiro 1987. Sluka \& Sullivan 1996b). Small species are graysby Cephalopholis cruentatus and coney C. fulva, both of which tend to remain relatively small (maximum length $<41 \mathrm{~cm}$ ) and reach sexual maturity between 16 and $25 \mathrm{~cm}$ TL (Thompson \& Munro 1978). Intermediate-size species are red hind Epinephelus guttatus and rock hind $E$. adscensionis, which attain a maximum size generally between 41 and $60 \mathrm{~cm}$ TL (Thompson \& Munro 1978, Potts \& Manooch 1995). Large species are Nassau grouper E. striatus and Mycteroperca spp. These species sexually mature between 42 and $50 \mathrm{~cm}$ TL (Shapiro 1987, Sadovy \& Colin 1995), and may attain a maximum size well over $90 \mathrm{~cm}$ TL (Thompson
\& Munro 1978, Manooch 1987, Manooch \& Mason 1987). These life history categories were used so that comparisons among regions would not be biased by differences in species abundance indicative of biogeographic patterns.

\section{RESULTS}

\section{Species composition and abundance related to fishing pressure}

Nine grouper species represented by the genera Cephalopholis (2 species), Epinephelus (4 species) and Mycteroperca ( 3 species) were identified in transect surveys among all study areas surveyed (Table 3). In the most intensively fished locations; e.g. southeastern Cuba and the Dominican Republic, only 3 and 5 species were identified along all transects, respectively. In the Florida Keys and lightly fished or wholly protected areas in the central Bahamas, from 7 to 9 grouper species were recorded. A notable result was the apparent absence of any Mycteroperca species within transects in 2 of the most intensively fished locations.

Mean densities of groupers (no. of ind. $100 \mathrm{~m}^{-2}$ ) exhibited significant variation among the 6 study areas for most species as determined by non-parametric analysis of variance: Cephalopholis cruentatus $(H=34.04$, $\mathrm{df}=5, \mathrm{p}<0.001)$, C. fulva $(H=29.71, \mathrm{df}=5, \mathrm{p}<0.001)$, Epinephelus striatus $(H=38.41, \mathrm{df}=5, \mathrm{p}<0.001)$, Mycteroperca bonạci $(H=19.32$, df $=5, \mathrm{p}<0.01)$,

Table 3. Mean (1 SD) density (no. of ind. $100 \mathrm{~m}^{-2}$ ) and percent relative abundance of grouper species in the Florida Keys, Bahamas, and northern Caribbean. Sites are arranged from heavily fished (left) to no-fishing (right). See Table 1 for sample sizes and site abbreviations. +: Species observed in study area but not encountered in visual transect surveys. ++: Species historically known from study area

\begin{tabular}{|c|c|c|c|c|c|c|}
\hline Species & GTMO & Dominican Republic & Florida Keys & S Exumas & N Exumas & ECLSP \\
\hline Cephalopholis cruentatus & $\begin{array}{c}2.30(1.30) \\
78.5\end{array}$ & $\begin{array}{c}0.95(0.49) \\
66.9\end{array}$ & $\begin{array}{c}0.97(1.10) \\
85.8\end{array}$ & $\begin{array}{c}0.16(0.49) \\
8.9\end{array}$ & $\begin{array}{c}0.60(0.87) \\
39.2\end{array}$ & $\begin{array}{c}0.27(0.55) \\
18.0\end{array}$ \\
\hline C. fulva & $\begin{array}{c}0.63(0.87) \\
21.5\end{array}$ & $\begin{array}{c}0.35(0.41) \\
5.6\end{array}$ & $\begin{array}{c}0.01(0.08) \\
0.9\end{array}$ & $\begin{array}{c}1.30(1.35) \\
72.6\end{array}$ & $\begin{array}{c}0.44(0.87) \\
28.8\end{array}$ & $\begin{array}{c}0.52(0.83) \\
34.7\end{array}$ \\
\hline Epinephelus adscensionis & & $\begin{array}{c}0.04(0.07) \\
2.8\end{array}$ & $\begin{array}{c}0.04(0.19) \\
3.5\end{array}$ & $\begin{array}{c}0.01(0.12) \\
0.6\end{array}$ & $\begin{array}{c}0.01(0.04) \\
0.7\end{array}$ & $\begin{array}{c}0.04(0.14) \\
.2 .7\end{array}$ \\
\hline E. guttatus & & $\begin{array}{c}0.08(0.11) \\
24.7\end{array}$ & $\begin{array}{c}0.04(0.21) \\
3.5\end{array}$ & $\begin{array}{c}0.13(0.37) \\
7.3\end{array}$ & $\begin{array}{c}0.20(0.43) \\
13.1\end{array}$ & $\begin{array}{c}0.14(0.41) \\
9.3\end{array}$ \\
\hline E. itajara & & & & & + & \\
\hline E. striatus & & ++ & $\begin{array}{c}0.01(0.11) \\
0.9\end{array}$ & $\begin{array}{c}0.16(0.37) \\
8.9\end{array}$ & $\begin{array}{c}0.20(0.43) \\
13.1\end{array}$ & $\begin{array}{c}0.35(0.55) \\
23.3\end{array}$ \\
\hline Mycteroperca bonaci & & & $\begin{array}{c}0.04(0.21) \\
3.5\end{array}$ & & $\begin{array}{c}0.01(0.14) \\
0.7\end{array}$ & $\begin{array}{c}0.01(0.14) \\
0.7\end{array}$ \\
\hline M. tigris & & ++ & $\begin{array}{c}0.02(0.14) \\
1.8\end{array}$ & $\begin{array}{c}0.01(0.37) \\
0.6\end{array}$ & $\begin{array}{c}0.06(0.29) \\
3.9\end{array}$ & $\begin{array}{c}0.12(0.28) \\
8.0\end{array}$ \\
\hline$M$. venenosa & & ++ & ++ & $\begin{array}{c}0.02(0.12) \\
1.1\end{array}$ & $\begin{array}{c}0.01(0.14) \\
0.7\end{array}$ & $\begin{array}{c}0.05(0.14) \\
3.3\end{array}$ \\
\hline
\end{tabular}



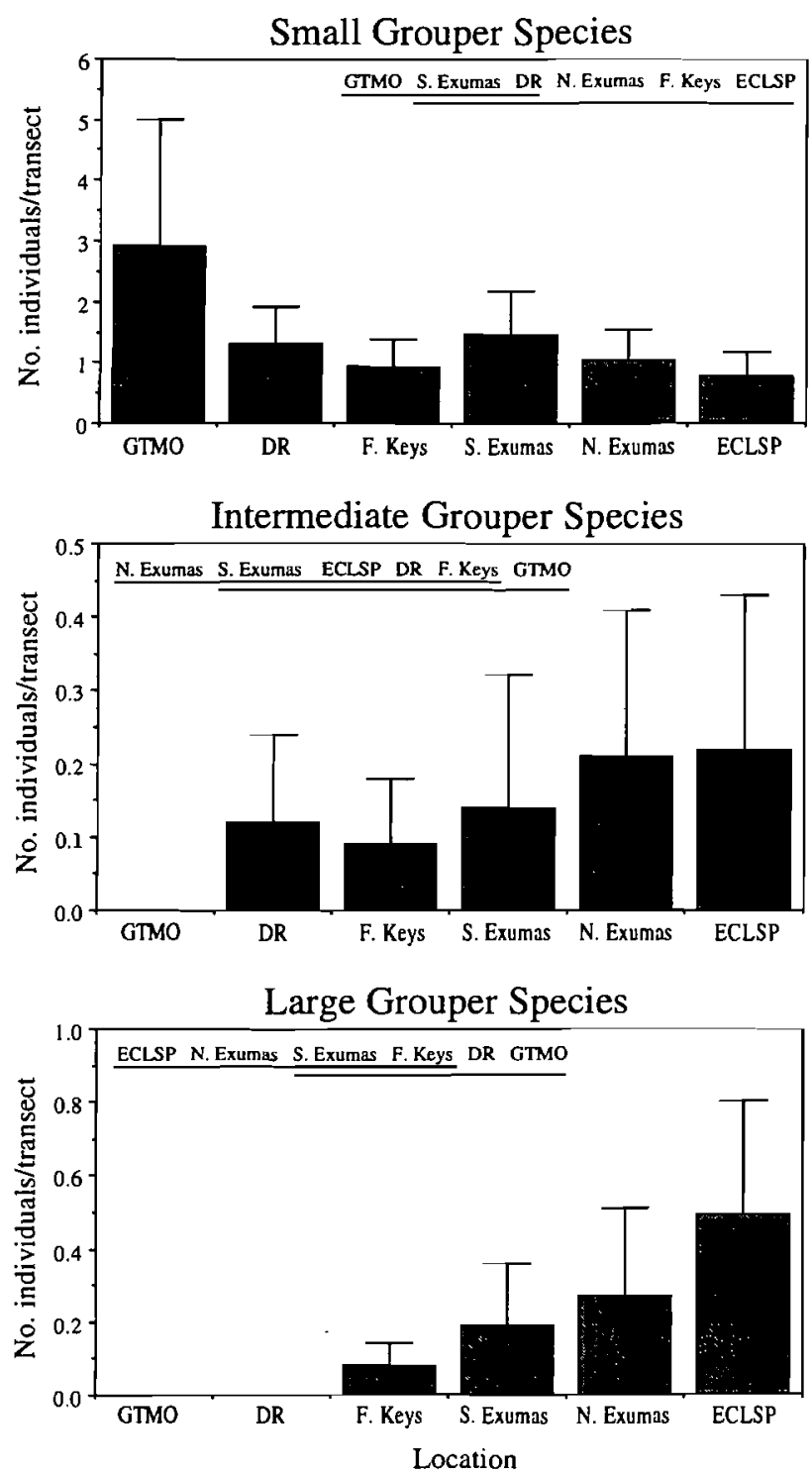

Fig. 2. Mean density of groupers (no. of ind. $100 \mathrm{~m}^{-2}$ ) based on life history categories in southeastern Cuba (GTMO), southeastern Dominican Republic (DR), Florida Keys, and central Bahamas. Error bars represent 1 SD. Refer to Table 1 for samples sizes and site abbreviations. Small grouper species = Cephalopholus cruentatus and C. fulvus; Intermediate $=$ Epinephelus adscensionis and $E$. guttatus; Large $=E$. striatus, Mycteroperca bonaci, $M$. tigris and $M$. venenosa. Lines connecting sites are not significantly different $(\mathrm{p}<0.05)$ as determined by parametric or non-parametric multiple comparisons (Tukey test)

$M$. tigris $(H=15.89, \mathrm{df}=5, \mathrm{p}<0.01)$, and $M$. venenosa $(H=11.85, \mathrm{df}=5, \mathrm{p}<0.05)$ (Table 3$)$. Non-targeted species (C. cruentatus and $C$. fulva) were significantly more abundant in intensively fished regions, while larger groupers were significantly more abundant in lightly fished regions and the no-take marine reserve. This pattern was particularly prevalent for E. striatus, which was 6 times more abundant in the no-take marine reserve than in the Florida Keys, as well as 2 times greater than in the northern and southern Exumas. The relative abundance of grouper species indicated that intensively fished regions were dominated ( $>85 \%$ of total density) by non-targeted species (C. cruentatus and C. fulva), while larger, targeted species represented a greater percentage of the grouper assemblage in lightly fished areas of the Bahamas (Table 3). For example, E. striatus and Mycteroperca spp. comprised over $30 \%$ of the groupers surveyed in the marine fishery reserve.

Analysis of grouper density patterns by life history category further demonstrated patterns probably related to fishing intensity (Figs. $2 \& 3$ ). Analysis of variance on root-root transformed density data showed that the mean density of small grouper species was generally greater in intensively fished areas ( $F$-test, df $=5, p<0.01$ ). Non-parametric analysis of variance for large grouper species showed that density was

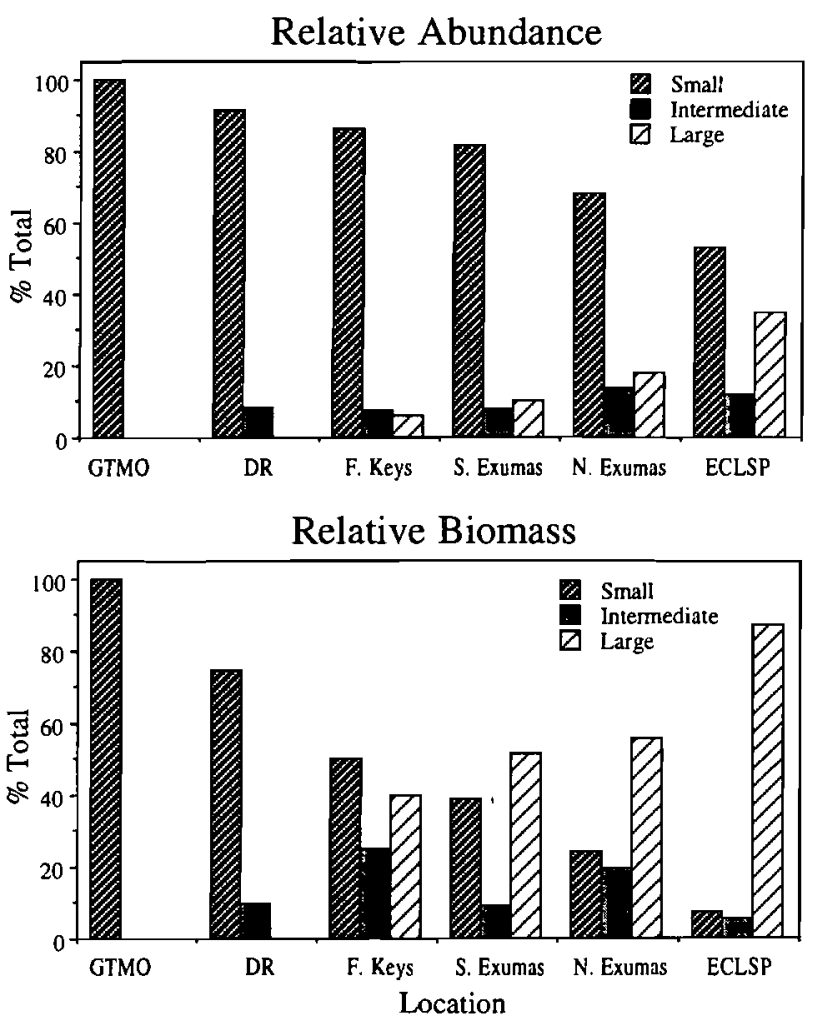

Fig. 3. Relative abundance and biomass of groupers based on life history categories in Guantanamo Bay Naval Base, southeastern Cuba (GTMO), southeastern Dominican Republic (DR), Florida Keys, southern and northern Exumas, central Bahamas, and the Exuma Cays Land and Sea Park, central Bahamas. Small grouper species = Cephalopholis cruentatus and $C$. fulvus; Intermediate $=$ Epinephelus adscensionis and E. guttatus; Large $=E$. striatus, Mycteroperca bonaci, $M$. tigris and $M$. venenosa 
Table 4. Mean (1 SD) total length (cm) and numbers of individuals sampled, and size range of grouper species in the Florida Keys, central Bahamas, and northern Caribbean. Sites are arranged from heavily fished (left) to no-fishing (right). See Table 1 for site abbreviations

\begin{tabular}{|c|c|c|c|c|c|c|}
\hline Species & GTMO & Dominican Republic & Florida Keys & S Exuma & N Exuma & ECLSP \\
\hline $\begin{array}{c}\text { Cephalopholis } \\
\text { cruentatus }\end{array}$ & $\begin{array}{l}15.2(3.7)(372) \\
6-25\end{array}$ & $\begin{array}{l}18.4(4.9)(5) \\
5-30\end{array}$ & $\begin{array}{c}17.8(4.6)(153) \\
6-31\end{array}$ & $\begin{array}{l}18.9(5.6)(24) \\
9-32\end{array}$ & $\begin{array}{l}15.8(3.3)(127) \\
9-28\end{array}$ & $\begin{array}{l}15.5(3.8)(52) \\
10-28\end{array}$ \\
\hline C. fulva & $\begin{array}{l}17.1(4.8)(72) \\
6-31\end{array}$ & $\begin{array}{l}18.7(4.7)(52) \\
10-36\end{array}$ & $\begin{array}{l}17.0(0)(1) \\
17\end{array}$ & $\begin{array}{c}16.1(2.7)(171) \\
6-21\end{array}$ & $\begin{array}{l}17.7(2.9)(90) \\
9-24\end{array}$ & $\begin{array}{l}16.3(3.6)(96) \\
10-28\end{array}$ \\
\hline $\begin{array}{l}\text { Epinephelus } \\
\text { adscensionis }\end{array}$ & & $\begin{array}{l}25.0(2.8)(2) \\
23-27\end{array}$ & $\begin{array}{l}23.7(7.5)(6) \\
16-35\end{array}$ & $\begin{array}{l}30.5(2.1)(2) \\
29-32\end{array}$ & $\begin{array}{l}31.0(1.4)(2) \\
30-32\end{array}$ & $\begin{array}{l}24.0(10.0)(7) \\
11-40\end{array}$ \\
\hline E. guttatus & & $\begin{array}{l}23.0(6.6)(11) \\
13-32\end{array}$ & $\begin{array}{l}22.7(3.8)(7) \\
18-30\end{array}$ & $\begin{array}{l}25.0(3.0)(19) \\
19-31\end{array}$ & $\begin{array}{l}28.0(4.8)(42) \\
18-42\end{array}$ & $\begin{array}{l}25.1(6.4)(27) \\
9-36\end{array}$ \\
\hline E. striatus & & & $\begin{array}{l}42.5(10.6)(2) \\
35-50\end{array}$ & $\begin{array}{l}33.8(10.9)(24) \\
22-61\end{array}$ & $\begin{array}{l}35.7(11.3)(47) \\
17-65\end{array}$ & $\begin{array}{l}41.8(12.4)(67) \\
20-73\end{array}$ \\
\hline $\begin{array}{l}\text { Mycteroperca } \\
\text { bonaci }\end{array}$ & & & $\begin{array}{l}39.6(13.6)(7) \\
25-65\end{array}$ & & $\begin{array}{l}45.0(0)(1) \\
45\end{array}$ & $\begin{array}{l}92.5(3.5)(2) \\
90-95\end{array}$ \\
\hline $\begin{array}{l}\text { M. tigris } \\
M . \text { venenosa }\end{array}$ & & $\therefore-=-$ & $\begin{array}{l}38.3(14.4)(3) \\
30-55\end{array}$ & $\begin{array}{l}41.0(0)(1) \\
41 \\
66.7(6.4)(3) \\
63-74\end{array}$ & $\begin{array}{l}31.4(8.4)(11) \\
22-47 \\
49.0(4.2)(2) \\
46-52\end{array}$ & $\begin{array}{l}36.5(11.8)(21) \\
13-60 \\
56.3(20.7)(8) \\
26-75\end{array}$ \\
\hline
\end{tabular}

also significantly different among the 6 study areas ( $H=26.2, \mathrm{df}=5, \mathrm{p}<0.001)$ and showed a clear increase from intensively fished areas to the marine fishery reserve (Fig. 2). In intensively fished areas, for example, smaller-groupers comprised 86 to $100 \%$ of the individuals surveyed. In lightly fished areas and the no-take marine reserve, however, smaller groupers comprised 53 to $82 \%$ of the total groupers recorded. While large grouper species were either absent, or only accounted for approximately $6 \%$ of the total groupers in intensively fished locations, they comprised 10 to $35 \%$ in lightly fished areas and the marine fishery reserve.

\section{Grouper size and biomass in fished and protected areas}

Because of some biogeographic differences in species composition, sample size and the abundance of groupers, formal statistical comparisons of grouper size were not attempted. Graysby Cephalopholis cruentatus had the smallest mean TL in lightly fished areas or the no-take marine reserve, but had on average a 2 to $3 \mathrm{~cm}$ greater mean TL in intensively fished areas (Table 4). The exception to this pattern was southeastern Cuba, where many small individuals of this species were observed at 1 site. Larger grouper

Table 5. Mean (1 SD) biomass ( $100 \mathrm{~m}^{-2}$ ) and percent relative biomass of grouper species in the Florida Keys, central Bahamas, and northern Caribbean. Sites are arranged from heavily fished (left) to no-fishing (right). See Table 1 for sample sizes and site abbreviations

\begin{tabular}{|lccccccc}
\hline Species & GTMO & Dominican Republic & Florida Keys & . S Exuma & N Exuma & ECLSP \\
\hline Cephalopholis & $136.0(63.0)$ & $96.1(73.9)$ & $103.6(136.6)$ & $21.9(40.0)$ & $40.3(41.6)$ & $18.2(18.5)$ \\
cruentatus & 65.4 & 50.8 & 49.1 & 5.2 & 10.3 & 1.8 \\
C. fulva & $71.9(117.1)$ & $45.5(54.8)$ & $0.7(8.6)$ & $143.4(80.4)$ & $54.5(54.7)$ & $54.7(44.8)$ \\
& 34.6 & 24.0 & 0.3 & 34.0 & 14.0 & 5.5 \\
Epinephelus & & $29.7(66.7)$ & $11.5(77.4)$ & $6.9(18.5)$ & $5.2(16.4)$ & $13.6(40.8)$ \\
adscensionis & & 15.7 & 5.5 & 1.6 & 1.3 & 1.4 \\
E. guttatus & & $18.0(24.6)$ & $8.8(45.7)$ & $31.2(40.3)$ & $71.7(66.8)$ & $40.5(67.0)$ \\
& & 9.5 & 4.2 & 7.4 & 18.4 & 4.0 \\
E. striatus & & & $15.7(156.4)$ & $118.0(145.7)$ & $166.5(213.4)$ & $495.7(370.2)$ \\
& & & 7.4 & 27.9 & 42.7 & 49.4 \\
Mycteroperca & & & $29.5(340.6)$ & & $5.7(26.1)$ & $121.4(365.0)$ \\
bonaci & & & $21.2(206.7)$ & $6.7(26.1)$ & $28.8(59.8)$ & $101.8(142.0)$ \\
M. tigris & & 10.1 & 1.6 & 7.4 & 10.1 \\
M. venenosa & & & & $94.3(276.3)$ & $17.5(56.2)$ & $158.5(370.6)$ \\
& & & & & 4.5 & 15.8 \\
\hline
\end{tabular}



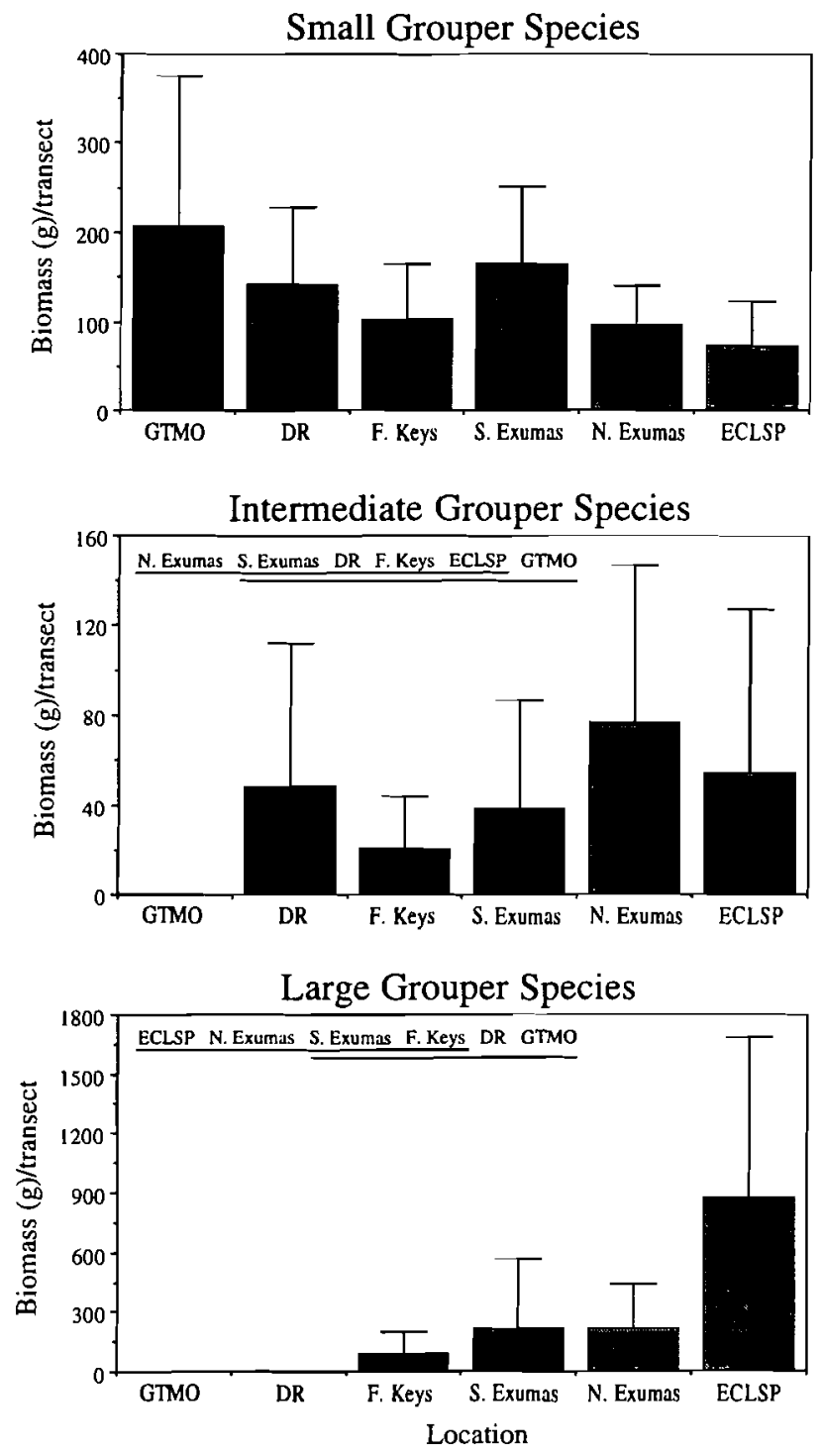

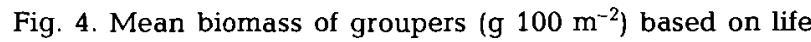
history categories in southeastern Cuba, southeastern Dominican Republic (DR), Florida Keys, and central Bahamas. Error bars represent 1 SD. Refer to Table 1 for samples sizes and to Fig. 2 legend for site abbreviations. Small grouper species $=$ Cephalopholis cruentatus and $C$. fulvus; Intermediate $=$ Epinephelus adscensionis and E. guttatus; Large = $E$. striatus, Mycteroperca bonaci, $M$. tigris and $M$. venenosa. Lines connecting sites are not significantly different $(p<0.05)$ as determined by parametric or non-parametric multiple comparisons (Tukey test)

species generally showed a pattern of greater mean size and range in size in lightly fished areas and the ECLSP. This was particularly evident even among areas in the central Bahamas for Nassau grouper Epinephelus striatus, where, on average, individuals were 6 to $7 \mathrm{~cm}$ larger in the ECLSP than in the northern and southern Exumas.
The grouper biomass per unit area, an integrated measure of density and length, exhibited many predictable patterns to fishing pressure as density (Table 5). Non-parametric ANOVA showed that mean grouper biomass (g $100 \mathrm{~m}^{-2}$ ) differed significantly among locations for most species: Cephalopholis cruentatus $(H=30.83, \mathrm{df}=5, \mathrm{p}<0.001), C$. fulva $(H=27.45, \mathrm{df}=5$ $\mathrm{p}<0.001)$, Epinephelus guttatus $(H=12.86$, df $=5$, $\mathrm{p}<0.05), E$. striatus $(H=38.07, \mathrm{df}=5, \mathrm{p}<0.001)$ Mycteroperca bonaci $(H=18.13, \mathrm{df}=5, \mathrm{p}<0.01)$, $M$. tigris $(H=16.28, \mathrm{df}=5, \mathrm{p}<0.01)$, and $M$. venenosa $(H=11.44, \mathrm{df}=5, \mathrm{p}<0.05)$. Non-targeted species (C. cruentatus and C. fulva) generally had greater biomass per unit area in intensively fished regions, while larger groupers had greater biomass in lightly fished regions and the ECLSP. This was especially true for E. striatus, whose mean biomass per unit area was over 30 times greater in the no-take marine reserve than in the Florida Keys, but also 3 to 4 times greater than in the lightly fished northern and southern Exumas. Relative biomass data showed that intensively fished regions were dominated ( 50 to $100 \%$ ) by smaller, nontarget species (C. cruentatus and C. fulva), while lightly fished regions ( 44 to $50 \%$ ) and the marine fishery reserve $(14 \%)$ were dominated by larger species.

Analysis of grouper biomass patterns by life history category illustrated certain patterns among locations probably related to relative fishing intensity (Figs. 3 \& 4). Although significant differences in small grouper density were noted, mean biomass (log-transformed) was not significantly different among the 6 study areas ( $F$-test, $\mathrm{df}=5, \mathrm{p}=0.09$ ); however, small grouper biomass was lowest in the lightly fished northern Exumas and the ECLSP (Fig. 4). In contrast, the mean biomass of larger grouper species showed a clear pattern of increasing mean biomass per unit area with degree of protection ( $H=26.0$, df $=5, p<0.001)$. When relative biomass by life history was explored, differences among locations were even more evident (Fig. 3). In southeastern Cuba and the southeastern Dominican Republic, for example, 75 to $100 \%$ of the grouper biomass was comprised of small species. In contrast, nearly $90 \%$ of the grouper biomass in the ECLSP was comprised of larger, targeted species.

\section{DISCUSSION}

Existing data on the status of grouper stocks in the wider Caribbean provides undeniable evidence of the vulnerability of these fishes to even relatively low fishing pressure. This appears to be particularly true in areas lacking catch and effort regulations (Gobert 1994, Sadovy 1994, Luckhurst 1996) and demonstrates that grouper abundance, size distribution and inte- 
grated measures such as biomass are good indicators of fishing pressure (Russ 1985). Our results show that intensive fishing of shallow-water grouper resources has resulted in lower numbers of species, lower density, smaller size, and lower biomass of larger species, but also differences in species composition and dominance patterns. Intensively fished areas exhibited lower species richness, reflecting a dominance by smaller, non-targeted species. In 2 of the intensively fished areas, no larger species were found in over 100 visual transects surveyed. Along a gradient of decreasing fishing intensity, the relative abundance and biomass of small grouper species decreased, while the relative abundance and biomass of large groupers increased. Analysis of grouper composition by growth history revealed dramatic patterns in abundance and biomass according to relative fishing intensity. We argue that this type of analysis minimized biogeographic differences in species composition by categorizing species according to similar theoretical maximum size. While these conclusions assume that fishing is the predominant factor affecting the differences in the abundance and size of groupers, Sluka et al. (1997) have shown that fishing pressure is a more important influence when considered simultaneously with habitat preference.

Groupers exhibit a classic fisheries response to heavy fishing pressure: changes.in catch composition from larger to smaller individuals and/or species over time (Gobert 1994, Luckhurst 1996). Greater abundance and biomass of non-targeted species in intensively fished areas possibly represents a second-order effect of fishing, potentially reflecting changes in competition or predation (Bohnsack 1982, Watson \& Ormond 1994, Jennings \&. Polunin 1996). Changes in competition and/or predation by fishing of larger species may allow smaller species to increase in abundance and size, due to the increase in resources available to them (Russ 1991). There are no data that we are aware of which suggest that larger grouper species prey upon smaller grouper species (Randall 1967). Although smaller species dominate grouper assemblages for wider Caribbean areas (Gobert 1994, Beets \& Friedlander 1992, Luckhurst 1996), the ecological changes brought about by shifts in species composition and relative abundance require further study.

Our study of groupers in the northern wider Caribbean clearly showed that protection from fishing with marine fishery reserves yielded greater species richness, density and biomass of large, targeted species. Even in the lightly fished northern and southern Exuma Cays, for example, the ECLSP has significantly greater density, size, biomass, and potential egg production for species such as Nassau grouper (Sluka et al. 1997). It is likely that this marine fishery reserve is an important source of larvae to the northern Exuma Cays (Sluka et al. 1996b), based upon circulation patterns and the presence of protected spawning aggregations (Colin 1995). This reserve also likely exports biomass to areas near the park $(<5 \mathrm{~km})$ through adult emigration (Sluka et al. 1997).

That relatively intensive fisheries management in the Florida Keys has not prevented the apparent decline of shallow-water grouper assemblages is cause for concern (Bohnsack et al. 1994, Ault et al. 1998). Despite intensive management in the US, fishermen perceptions are that grouper populations have continued to decline in number, mean size, and age (Huntsman et al. 1994). It is apparent that size limits alone do not prevent the removal of the largest groupers, and that significant mortality of smaller individuals will likely occur. Fisheries-dependent sampling and enforcement of catch and effort regulations are time-consuming, expensive, and logistically difficult, particularly in coral reef areas with multispecific fisheries and uneven effort distributed spatially at diverse landing points (Russ 1991). Marine reserves facilitate enforcement because there are no complex fishery regulations and only adequate numbers of personnel are needed to patrol the area (PDT 1990). When used in conjunction with traditional fisheries management approaches to prevent growth and perhaps recruitment overfishing, reserves offer a viable option to protect spawning stock biomass and enhance yields in adjacent areas (PDT 1990, Russ \& Alcala 1992). Marine fishery reserves have been shown to protect grouper resources in geographically diverse areas such as the Philippines (Russ \& Acala 1996), France (Harmelin et al. 1995), the Bahamas (Sluka et al. 1997) and Kenya (Samoilys 1988).

The recovery potential of intensively fished coastal areas will be a function of the status of stocks, the timing of fisheries decline, life history characteristics of species, availability of recruits to replenish fished areas, socioeconomic factors, political will, and the perception of a 'natural' state. Because grouper fishing is typically concentrated during the formation of spawning aggregations (Carter et al. 1994, Aguilar-Perera \& Aguilar-Davila 1996), the protection of spawning aggregations is necessary to ensure long-term population viability (Beets \& Friedlander 1992, Sadovy 1994). Few empirical data are available on recovery of fished regions after closure (Bohnsack 1982, Shpigel \& Fishelson 1991, Russ \& Alcala 1996). In the southeastern Dominican Republic, the recovery potential is likely to be particularly low, given that this area is down-current of the heavily fished eastern Caribbean (Beets \& Friedlander 1992, Sadovy 1994). In the Florida Keys, marine fishery reserves offer probably the only mechanism to evaluate the impacts of fishing in a diverse 
fishery characterized by multiple target species, gears, and objectives (Bohnsack et al. 1994). Even in lightly fished locations such as the central Bahamas, systems of marine reserves linked by circulation patterns, as well as specific protection of existing spawning aggregations, may represent the most reliable means to ensure the recovery and conservation of grouper populations.

Acknowledgements. The authors thank the following for their financial and logistical support: Florida Keys-The Nature Conservancy's Florida Keys Initiative, NOAA's National Undersea Research Program pursuant to grants UNCW9316/9420, the Florida Keys National Marine Sanctuary pursuant to permit FKNMS-9307, the University of Miami Marine Science Program, R. Bryant, G. Meester, A. Lowe, and B. Miller; Bahamas-The Jeniam Foundation, The Nature Conservancy's Caribbean Division, Bahamas Department of Fisheries, D. Doyle and the crew of RV 'Sea Dragon', $R$. Darville and the volunteer fleet of the Exuma Cays Land and Sea Park, and R. Gomez of the University of Miami for dive support; Dominican Republic-US Agency for International Development, The Nature Conservancy, Munson Foundation, J. Tschirky, PRONATURA, and the crew of the RV 'Coral Reef II'; Guantanamo Bay, Cuba-US Navy, Office of Public Works, R. Gomez and S. Bolden.

\section{LITERATURE CITED}

Aguilar-Perera A, Aguilar-Davila W (1996) A spawning aggregation of Nassau grouper Epinephelus striatus (Pisces: Serranidae) in the Mexican Caribbean. Environ Biol Fish 45:351-361

Ault JS, Bohnsack JA, Meester GA (1998) A retrospective (1979-1996) multispecies assessment of coral reef fish stocks in the Florida Keys. Fish Bull US 96:395-414

Beets J, Friedlander A (1992) Stock analysis and management strategies for red hind, Epinephelus guttatus, in the US Virgin Islands. Proc Gulf Caribb Fish Inst 42:66- 79

Bell JD, Craik GJS, Pollard DA, Russell BC (1985) Estimating length frequency distributions of large reef fish underwater. Coral Reefs 4:41-44

Bohnsack JA (1982) Effects of piscivorous predator removal on coral reef fish community structure. In: Cailliet GM, Simenstad CA (eds) Gutshop '81: Proceedings of the Third Pacific Workshop on Fish Food Habits Studies. Washington Sea Grant, Seattle, p 258-267

Bohnsack JA (1990) Black and Nassau grouper fishery trends. NMFS-SEFSC, Miami

Bohnsack JA, Harper DE, McClellan DB (1994) Fisheries trends from Monroe County, Florida. Bull Mar Sci 54: 982-1018

Carter J, Marrow GJ, Pryor V (1994) Aspects of the ecology and reproduction of Nassau grouper, Epinephelus striatus, off the coast of Belize, Central America. Proc Gulf Caribb Fish Inst 43:65-111

Chiappone M, Sullivan KM (1997) Rapid assessment of reefs in the Florida Keys: results from a synoptic survey. Proc 8th Int Coral Reef Symp 2:1509-1514

Chiappone M, Sullivan KM, Sluka R (1997) Status of reefs in the central Bahamas based on a large-scale survey. Proc 8th Int Coral Reef Symp 1:345-350

Claro R, Garcia-Arteaga JP (1994) Crecimiento. In: Claro R (ed) Ecologia de los peces marinos de Cuba. Centro de Investigaciones de Quintana Roo, Mexico, p 321-402

Colin PL (1995) Surface currents in Exuma Sound, Bahamas and adjacent areas with reference to potential larval transport. Bull Mar Sci 56:48-57

Dugan JE, Davis GE (1993) Applications of marine refugia to coastal fisheries management. Can J Fish Aquat Sci 50: 2029-2042

Ferry RE, Kohler CC (1987) Effects of trap fishing on fish populations inhabiting a fringing coral reef. N Am J Fish Manage 7:580-588

Garcia-Cagide A, Garcia T (1996) Reproduccion de Mycteroperca bonaci y Mycteroperca venenosa (Pisces: Serranidae) en Ia plataforma Cubana. Rev Biol Trop 44: $771-780$

Gobert B (1994) Preliminary analysis of the exploitation of groupers in Martinique. Proc Gulf Caribb Fish Inst 43: $446-455$

Goeden GB (1982) Intensive fishing and a 'keystone' predator species: ingredients for community instability. Biol Conserv 22:273-281

Harmelin JG, Bachet F, Garcia F (1995) Mediterranean marine reserves: fish indices as tests of protection efficiency. PSZN I: Mar Ecol 16:233-250

Huntsman GR, Schaaf WE (1994) Simulation of the impact of fishing on reproduction of a protogynous grouper, the graysby. N Am J Fish Manage 14:41-52

Huntsman GR, Potts J, Mays RW (1994) A preliminary assessment of the populations of seven species of grouper (Serranidae, Epinephilinae) in the western Atlantic Ocean from Cape Hatteras, North Carolina to the Dry Tortugas, Florida. Proc Gulf Caribb Fish Inst 43:193-213

Jennings S, Polunin NVC (1996) Impacts of fishing on tropical reef ecosystems. Ambio 25:44-49

Luckhurst BE (1996) Trends in commercial fishery landings of groupers and snappers in Bermuda from 1975 to 1992 and associated fishery management issues. In: ArreguinSanchez F, Munro JL, Balgos MC, Pauly D (eds) Biology, fisheries and culture of tropical groupers and snappers. ICLARM Conference Proceedings 48, ICLAM, Manila, p 277-288

Manooch CS (1987) Age and growth of snappers and groupers. In: Polovina JJ, Ralston S (eds) Tropical snappers and groupers: biology and fisheries management. Westview Press, Boulder, CO, p 329-372

Manooch CS, Mason DL (1987) Age and growth of the warsaw grouper and black grouper from the southeast region of the United States. Northeast Gulf Sci 9:65-75

Nagelkerken WP (1981) Distribution of the groupers and snappers of the Netherlands Antilles. Proc 4th Int Coral Reef Symp 2:479-484

Olsen DA, LaPlace JA (1978) A study of a Virgin Island grouper fishery based on a breeding aggregation. Proc Gulf Caribb Fish Inst 31:130-144

Parrish JD (1987) The trophic biology of snappers and groupers. In: Polovina JJ, Ralston S (eds) Tropical snappers and groupers: biology and fisheries management. Westview Press, Boulder, CO, p 405-463

Plan Development Team (PDT) (1990) The potential of marine fishery reserves for reef fish management in the US Southern Atlantic. NOAA Tech Mem NMFS-SEFC-261

Polunin NVC, Roberts CM (1993) Greater biomass and value of target coral-reef fishes in two small Caribbean marine reserves. Mar Ecol Prog Ser 100:167-176

Potts JC, Manooch CS (1995) Age and growth of red hind and rock hind collected from North Carolina through the Dry Tortugas, Florida. Bull Mar Sci 56:784 -794 
Randall JE (1967) Food habits of reef fishes of the West Indies. Stud Trop Oceanogr 5:665-847

Russ GR (1985) Effects of protective management on coral reef fishes in the central Philippines. Proc 5th Int Coral Reef Congr 4:219-224

Russ GR (1991) Coral reef fisheries: effects and yields. In: Sale PF (ed) The ecology of fishes on coral reefs. Academic Press, New York, p 601-635

Russ GR, Alcala AC (1989) Effects of intense fishing pressure on an assemblage of coral reef fishes. Mar Ecol Prog Ser $56: 13-27$

Russ GR, Alcala AC (1996) Marine reserves: rates and patterns of recovery and decline of large predatory fish. Ecol Appl 6:947-961

Russ GR, Alcala AC, Cabanban AS (1992) Marine reserves and fisheries management on coral reefs with preliminary modelling of the effects on yield per recruit. Proc 7 th Int Coral Reef Symp 2:978-985

Sadovy Y (1994) Grouper stocks of the western central Atlantic: the need for management and management needs. Proc Gulf Caribb Fish Inst 43:43-64

Sadovy $Y$ (in press) The case of the disappearing grouper: Epinephelus striatus, the Nassau grouper, in the Caribbean and western Atlantic. Proc Gulf Caribb Fish Inst 45

Sadovy Y, Colin PL (1995) Sexual development and sexuality in the Nassau grouper. J Fish Biol 46:961-976

Samoilys MA (1988) Abundance and species richness of coral reef fish on the Kenyan coast: the effects of protective management and fishing. Proc 6th Int Coral Reef Symp 2: 261-266

Shapiro DY (1987) Reproduction in groupers. In: Polovina JJ, Ralston S (eds) Tropical snappers and groupers: biology and fisheries management. Westview Press, Boulder, CO, p 295-327

Shpigel M, Fishelson L (1989) Habitat partitioning between species of the Genus Cephalopholis (Pisces, Serranidae) across the fringing reef of the Gulf of Aquaba (Red Sea). Mar Ecol Prog Ser 58:17-22

Shpigel M, Fishelson L (1991) Experimental removal of pis-

Editorial responsibility: Otto Kinne (Editor), Oldendorf/Luhe, Germany civorous groupers of the genus Cephalopholis (Serranidae) from coral habitats in the Gulf of Aqaba (Red Sea). Environ Biol Fish 31:131-138

Sluka R, Sullivan KM (1996a) Daily activity patterns of groupers in the Exuma Cays Land and Sea Park, central Bahamas. Bahamas J Sci 3:17-22

Sluka R, Sullivan KM (1996b) The influence of habitat on the size distribution of groupers in the upper Florida Keys. Environ Biol Fish 47:177-189

Sluka R, Chiappone M, Sullivan KM (1996a) Habitat preferences of groupers in the Exuma Cays. Bahamas J Sci 4 : 8-14

Sluka R, Chiappone M, Sullivan KM, Wright R (1996b) Habitat and life in the Exuma Cays, The Bahamas: the status of groupers and coral reefs in the northern cays. Media Publishing, Nassau

Sluka R, Chiappone M, Sullivan KM, Wright R (1997) The benefits of a marine fishery reserve for Nassau grouper Epinephelus striatus in the central Bahamas. Proc 8th Int Coral Reef Symp 2:1961-1964

Smith CL (1972) A spawning aggregation of Nassau grouper, Epinephelus striatus (Bloch). Trans Am Fish Soc 2:257-261

Thompson R, Munro JL (1978) Aspects of the biology and ecology of Caribbean reef fishes: Serranidae (hinds and groupers). J Fish Biol 12:115-146

Towle EL, Rainey WE, LaBastille A, McEachern J (1973) Terrestrial wildlife, marine habitats and management aspects of marine oriented recreation in the proposed Parque Nacionale del Este, Dominican Republic. Island Resources Foundation, St. Thomas, USVI

Vega $M$, Chiappone M, Delgado GA, Wright $R$, Sullivan KM (1996) Evaluacion ecologica integral: Parque Nacional del Este, Republica Dominicana. Tomo 2: Recursos marinos. Media Publishing, Nassau

Watson M, Ormond RFG (1994) Effect of an artisanal fishery on the fish and urchin populations of a Kenyan coral reef. Mar Ecol Prog Ser 109:115-129

Zar JH (1996) Biostatistical analyses, 3rd edn. Prentice Hall, Englewood Cliffs, NJ

Submitted: April 26, 1999; Accepted: November 16, 1999 Proofs received from author(s): May 15, 2000 